\title{
Territorial and Duet Calls of Three Malaysian Owl Species
}

(Panggilan Kewilayahan dan Berdua-dua Tiga Spesies Burung Hantu Malaysia)

\author{
Siew Ann Yee, Chong LeOng PuAN* \& PhoOI KuAn Chang
}

\begin{abstract}
Vocalisations of tropical birds are still largely unexplored particularly the nocturnal species. This study examined and quantitatively described the territorial calls and duets of the Sunda Scops-Owl (Otus lempiji), Brown Boobook (Ninox scutulata) and Spotted Wood-Owl (Strix seloputo) based on 105 territorial call and four duetting recordings collected from one forest reserve and oil palm smallholdings in Selangor, Peninsular Malaysia. Wilcoxon signed-rank tests found significant differences $(\mathrm{p}<0.05)$ for almost all vocal parameters measured from the spectrograms derived from the duets with one higher-pitched than the other. Being the first study to describe the vocal structure of the duetting calls of the three Malaysian strigids, this study serves as a baseline for future behavioural study of nocturnal birds particularly pertaining to conspecific interactions in the Sunda region.
\end{abstract}

Keywords: Duet; spectrogram; territorial call; tropical nocturnal bird; vocalisation

\section{ABSTRAK}

Penyuaraan burung tropika masih belum diterokai terutamanya spesies malam. Kajian ini melihat dan secara kuantitatif menggambarkan panggilan kewilayahan dan berdua-dua Burung Jampuk (Otus lempiji), Burung Betemak (Ninox scutulata) dan Burung Carik-kafan (Strix seloputo) berdasarkan 105 rakaman panggilan kewilayahan dan empat berduadua yang dikumpulkan dari satu hutan rizab dan ladang kelapa sawit di Selangor, Semenanjung Malaysia. Ujian pangkat bertanda Wilcoxon mendapati terdapat perbezaan yang signifikan $(\mathrm{p}<0.05)$ untuk hampir semua parameter vokal yang diukur daripada spektrogram yang diperoleh daripada berdua-dua dengan satu nada yang lebih tinggi daripada yang lain. Sebagai kajian pertama untuk menggambarkan struktur vokal panggilan merangkumi tiga spesies burung hantu di Malaysia, kajian ini berfungsi sebagai garis dasar untuk kajian tingkah laku masa depan burung malam terutama berkaitan dengan interaksi spesies yang sama di rantau Sunda.

Kata kunci: Berdua-dua; burung hantu tropika; panggilan kewilayahan; penyuaraan; spektrogram

\section{INTRODUCTION}

For birds, vocalisation is a primary means of communication (Catchpole \& Slater 2008) including providing sexual signal for territory defence and mate attraction. Territorial call is often performed by male birds (Catchpole \& Slater 2008; Fedy \& Stutchbury 2005; Langmore 1998; Martínez \& Zuberogoitia 2002). On the other hand, duets are either mixed or highly synchronised antiphonal vocalisations uttered by breeding pairs which also serve various biological functions pertaining to sexual as well as conspecific interactions (Hall 2004; Langmore 1998; Marshall-Ball et al. 2006; Slater \& Mann 2004). While duetting has been frequently described for diurnal passerines (Slater \& Mann 2004; Wachtmeister 2001), there is relatively less published works that described such behaviour in nocturnal birds (e.g. Odom \& Mennill 2010; Rasmussen et al. 2012), despite the latter is often vocally rather than visually more detectable in the wild.

Sunda Scops-Owl (Otus lempiji), Brown Boobook (Ninox scutulata) and Spotted Wood-Owl (Strix seloputo) are three resident owl species (Strigidae) that are fairly common in Malaysia. These strigids can be found in wooded habitats including parks and plantations (Jeyarajasingam 2012; König \& Weick 2008). It is only until the recent decade that more ecological information is available on these birds (e.g. Lok et al. 2009; Najmi-Hanis et al. 2016; Pilla et al. 2018; Puan et al. 2015; Sadanandan et al. 2015; Yahya et al. 2016). However, their vocalisations are still largely unexplored, except those of King (2002) and Yee et al. (2016). Here, we presented the first quantitative description of the territorial calls and duets of the Sunda Scops-Owl, Brown Boobook and Spotted Wood-Owl. As duets may be particularly rare to be encountered in the field yet useful in understanding the owls' behaviour, we documented such information for future reference based on the unpublished data subsequently collected from Yee et al. (2016).

\section{MATERIALS AND METHODS}

Nocturnal aural survey was made from December 2014 until June 2015 at Ayer Hitam Forest Reserve (2॰80’N, $101^{\circ} 39^{\prime} \mathrm{E}$ in Petaling district) and oil palm smallholdings at Tanjung Karang ( $3^{\circ} 23^{\prime} \mathrm{N}, 101^{\circ} 13^{\prime} \mathrm{E}$ in Kuala Selangor 
district) in Selangor, Peninsular Malaysia. The former is an isolated lowland dipterocarp forest of about 1,182 ha while the latter are agricultural lands of approximately 1,456 ha planted primarily with oil palms and intercropped with coconut, banana, mango, maize and cassava. The survey period fell under the breeding seasons of the owls (König \& Weick 2008; Najmi-Hanis et al. 2016; Yee et al. 2016).

Our survey was conducted at 1900-0100 h at predetermined sampling points (see Yee et al. 2016 for sampling details) using a Sennheiser ME66 shotgun microphone with a K6 power module and MZW 66 foam windshield connected to an Edirol R-09HR digital recorder. We recorded both territorial calls and duets for at least one minute each, during good weather and low wind speeds of less than $1 \mathrm{~m} / \mathrm{s}$. The recordings were made at a sampling frequency of $44.1 \mathrm{kHz}$ and stored as a 16-bit wave file.

To minimize measurement errors, we only selected high-quality spectrograms with less background noise for analysis. Depending on the displayed spectrograms (Figure 1 ), we measured temporal and frequency parameters in sec and in Hz, respectively, using Raven Pro 1.5 (Cornell Lab of Ornithology, New York, USA 2015 version). For the Sunda Scops-Owl (Figure 1(a)), there were two temporal (i.e. note duration (ND) and internote duration (INTD)) and six frequency parameters (start frequency (SF), end frequency $(\mathrm{EF})$, lowest frequency $(\mathrm{LF})$, highest frequency (HF), maximum frequency (MF) and mean fundamental frequency (MFF)). For the Brown Boobook (Figure 1(b)), the parameters taken were total note duration (TND), first and second lowest frequencies (1st and 2nd LF), first and second highest frequencies (1st and 2nd HF) as well as first and second start frequencies (1st and 2nd SF). For the Spotted Wood-Owl (Figure 1(c)), only ND, LF, HF and MFF were measured. For each duet, we randomly selected ten notes from each individual call and performed a Wilcoxon signed-rank test to test for significant differences for every parameter measured between the sexes.

The Sunda Scops-Owl in Peninsular Malaysia has only one type of territorial call which consists of a single whistle (Yee et al. 2016) regardless of the sexes (König $\&$ Weick 2008), thus we treated all spontaneous calls as territorial calls. The calls recorded from Brown Boobook were similar with the territorial song described by King (2002) and all spontaneously calls that fitted these criteria were assumed as their territorial calls. During the survey period, only one type of vocalisations was heard for Spotted Wood-Owl and the call was uttered by all individuals. The call was a pure note, loud and repetitive. These characteristics were similar with the general feature of territorial calls found in other owl species (König \& Weick 2008; Marshall 1978; Sangster et al. 2013). Thus, we considered the vocalisations recorded for Spotted Wood-Owls in the study as their territorial calls. We recorded both territorial calls and duets if paired owls were found at the same recording point.

\section{RESULTS AND DISCUSSION}

We collected 105 usable territorial call recordings of the three strigids (i.e. 75 recordings from 12 Sunda ScopsOwls, 16 from four Brown Boobooks and 14 from three Spotted Wood-Owls), majority of which were spontaneous calls. During the whole survey period, there were only two duets obtained for Sunda Scops-Owl (based on 17 multiple recording sessions) whereas there was only one duet collected for both Brown Boobook and Spotted Wood-Owl.

The territorial call of Sunda Scops-Owl was a loud woouk, often heard after dusk midnight (Najmi-Hanis et al. 2016). The call comprised a series of single note, with an upward inflection at the beginning of the call note, repeated monotonously at a regular interval (Figure 2). Since Yee et al. (2016) provided description of basic structure of territorial call of the owl, such details were not included here.

In the field, Brown Boobook often called soon after dusk. The territorial call was a hollow mellow double note, whoowup, with no audible gap between the two notes and has a rising inflection on the second note (König \& Weick 2008). The mean note duration for the whole double note was $0.38 \pm 0.06 \mathrm{sec}(n=4$ birds, range $=0.33-0.48 \mathrm{~s})$. The frequency for first note ranged from $0.30-0.78 \mathrm{kHz}$ whereas it was $0.39-0.99 \mathrm{kHz}$ for the second note. The double note

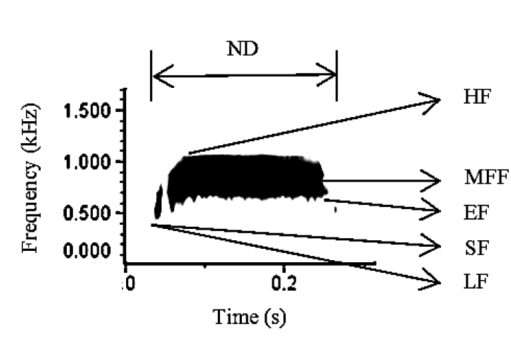

(a)

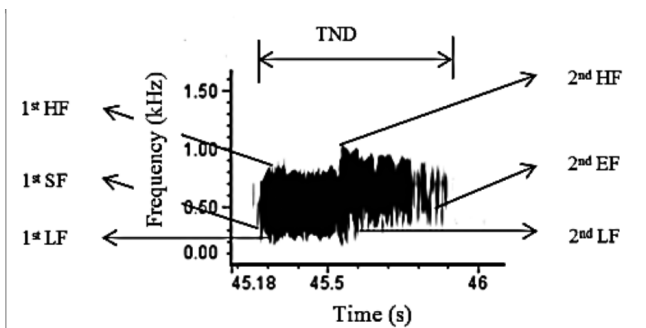

(b)

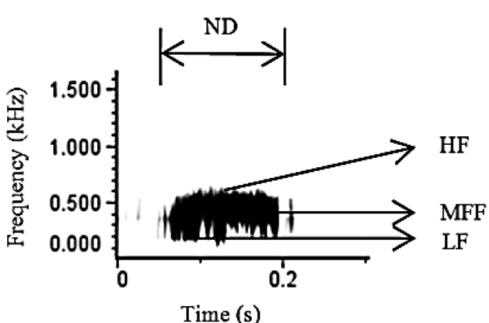

(c)

$(\mathrm{ND}=$ note duration, $\mathrm{INTD}=$ internote duration, $\mathrm{TND}=$ total note duration, $\mathrm{SF}=$ start frequency, $\mathrm{EF}=$ end frequency, $\mathrm{LF}=$ lowest frequency, $\mathrm{HF}=$ highest frequency, $\mathrm{MF}$ $=$ maximum frequency and MFF $=$ mean fundamental frequency)

FIGURE 1. Spectrograms of the calls of the Sunda Scops-Owl (a), Brown Boobook (b) and Spotted Wood-Owl

(c) indicating the temporal and frequency parameters measured 


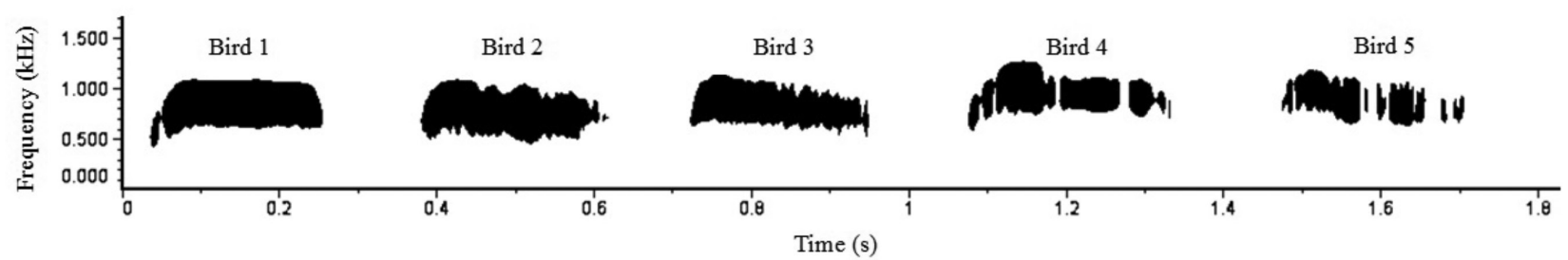

(a)

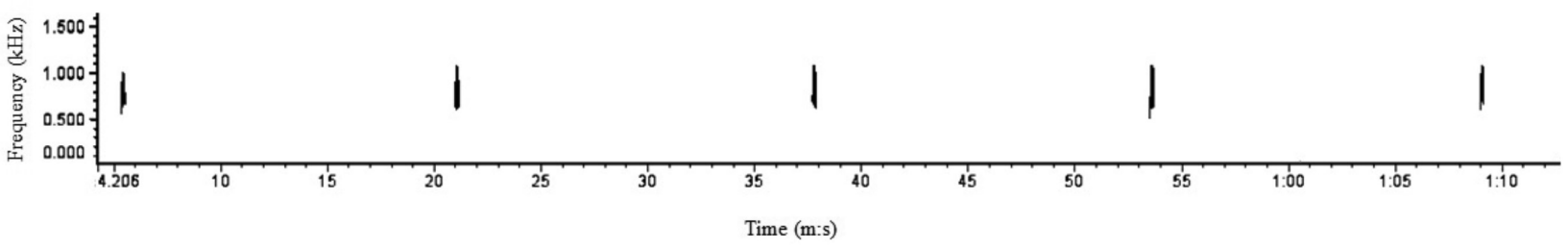

(b)

FIGURE 2. Spectrograms of territorial calls of Sunda Scops-Owl. All vocal notes from five different individuals were combined for illustration purpose on the same $x$-axis (a). The call was uttered monotonously in a continuous series at a relatively regular interval (b)

was uttered in a continuous series at intervals of $1.09 \pm$ $0.07 \mathrm{~s}(n=4$ birds, range $=0.96-1.28 \mathrm{~s})$, mostly in a row of 6-20 couplets, but sometimes can be up to 35 couplets (Figure 3).

As compared to Sunda Scops-Owl and Brown Boobook, the territorial call of Spotted Wood-Owl was rather deep and low-pitched (König \& Weick 2008), sounded whuu, which can be heard just after dusk and before dawn. The call made up of a series of single note with mean note duration around $0.15 \pm 0.01 \mathrm{~s}(n=3$ birds, range $=0.13-0.15 \mathrm{~s})$, uttered at a long interval of $11.10 \pm$ $3.98 \mathrm{~s}(n=3$ birds, range $=5.86-19.45 \mathrm{~s})$. The frequency

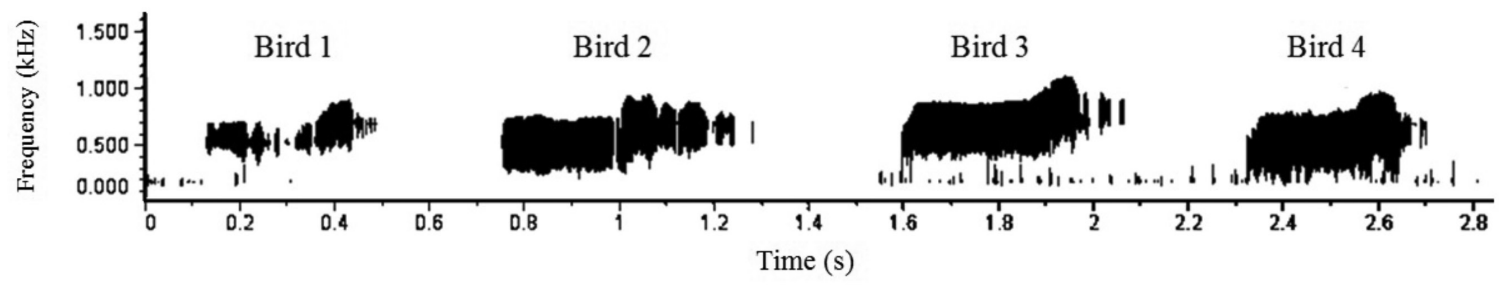

(a)

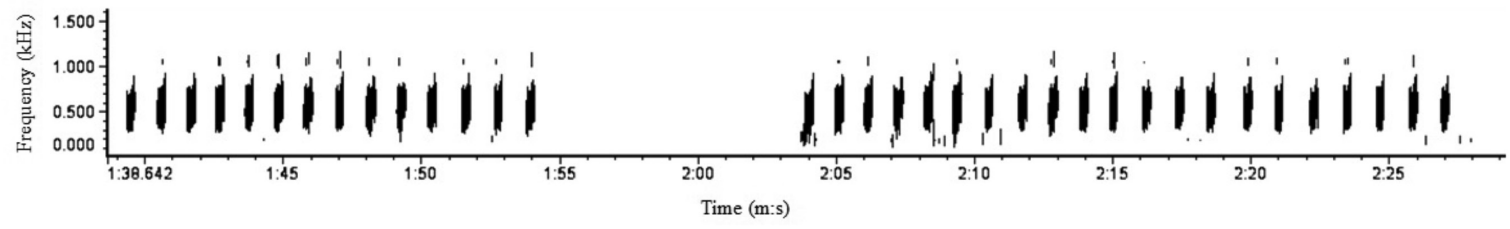

(b)

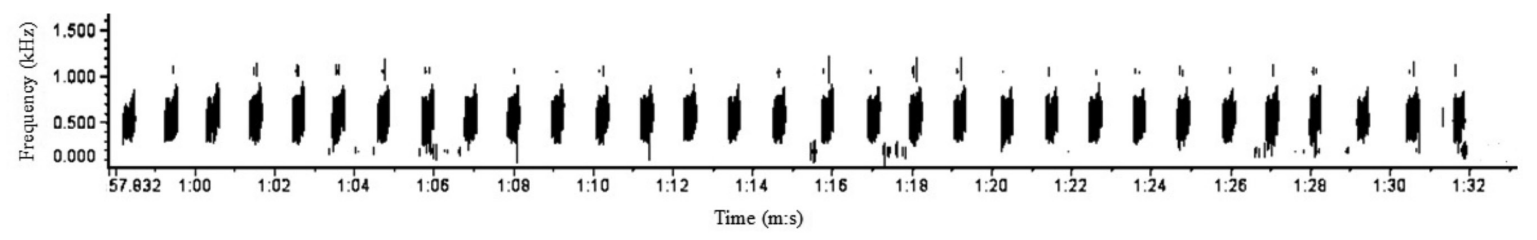

(c)

FIGURE 3. Spectrograms of territorial calls of Brown Boobook. All vocal notes from four different individuals were combined for illustration purpose on the same $x$-axis (a). The call was emitted in a continuous series, mostly in a row of 6-20 couplets

(b), but sometimes can be up to 31-35 couplets (c) 
of the call was relatively low, ranged from $0.11-0.68 \mathrm{kHz}$ (Figure 4).

Based on visual assessment and quantitative analysis of spectrograms, we found that the duets of Sunda ScopsOwl showed distinct differences in pitch between the sexes with one having a relatively higher frequency than the other (Figure 5). As König and Weick (2008) described female territorial calls were higher-pitched than that of male, those calls with higher frequency in a duet were suspected to be females. On average, the calls of presumed females were $50-200 \mathrm{kHz}$ higher than those of males.

Similar to Sunda Scops-Owl, the duets given by Brown Boobook and Spotted Wood-Owl also showed distinct differences in the call frequency (Figure 6). We suspected those higher-pitched calls were uttered by females. On average, the calls of presumed female
Brown Boobook were $30-100 \mathrm{kHz}$ higher than those of the male boobook and the calls of presumed female Spotted Wood-Owl were 60-100 kHz higher than those of the male. Wilcoxon signed-rank tests showed significant differences $(p<0.05)$ for almost all vocal parameters measured, except note duration for Sunda Scops Owl, internote duration and first highest frequency for Brown Boobook (Table 1).

However, since no owl was captured in the study, we cannot confirm the sexual differences in the vocalisations of the three owl species without performing molecular sexing. Nonetheless, the differences in the frequency of the calls suggested intersexual difference may exist in the vocalisations of these three owls, and sexes may be distinguished by their voices, albeit this awaits further research.

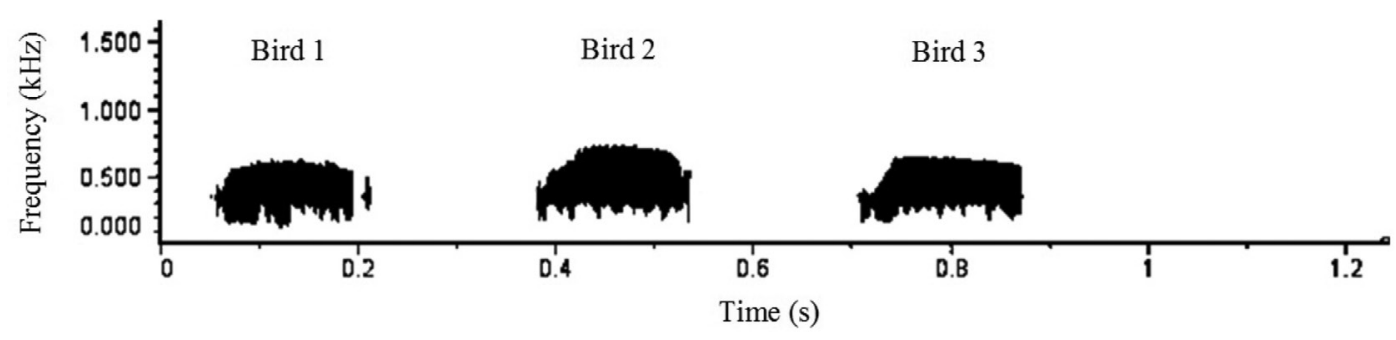

(a)

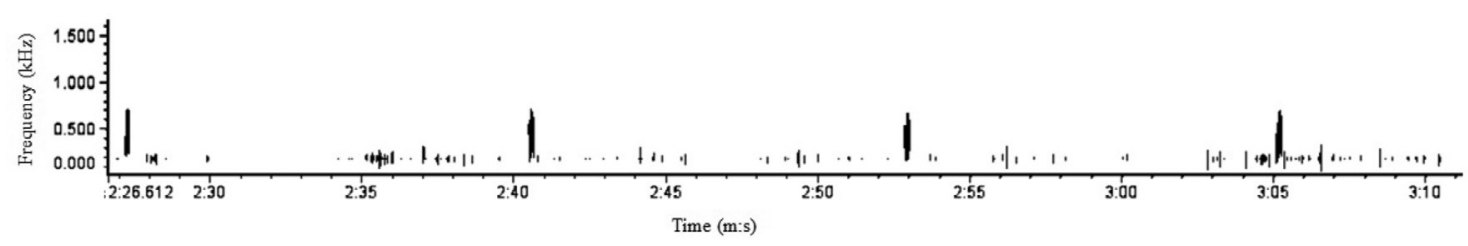

(b)

FIGURE 4. Spectrograms of territorial calls of Spotted Wood-Owl. All vocal notes from three different individuals were combined for illustration purpose on the same $x$-axis (a). The call was uttered monotonously in a continuous series at a long interval (b)

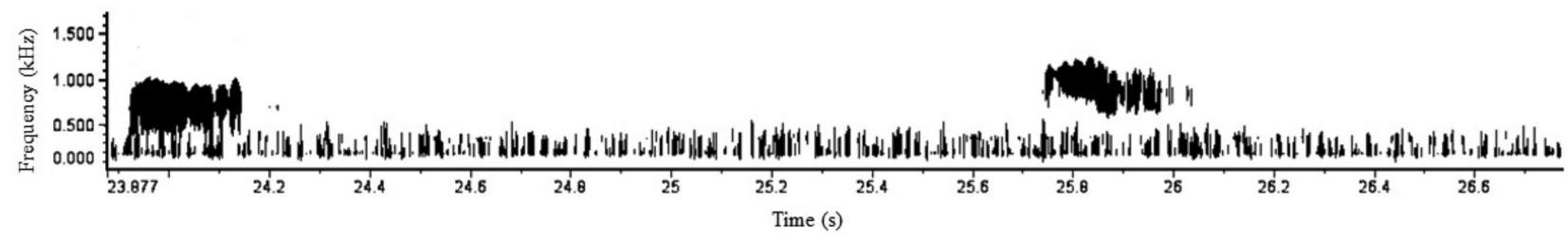

(a)

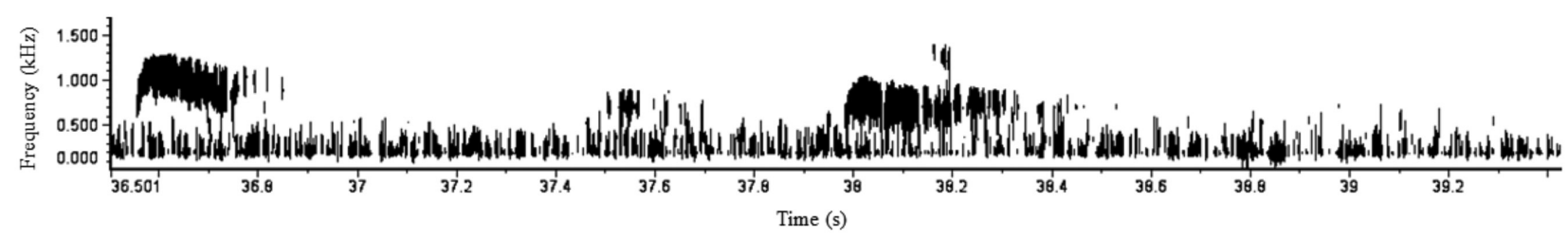

(b)

FIGURE 5. Spectrograms of duets recorded from two pairs of Sunda Scops-Owls, i.e. (a) Pair 1 and (b) Pair 2 . The calls of presumed females show higher frequency as compared to presumed males 


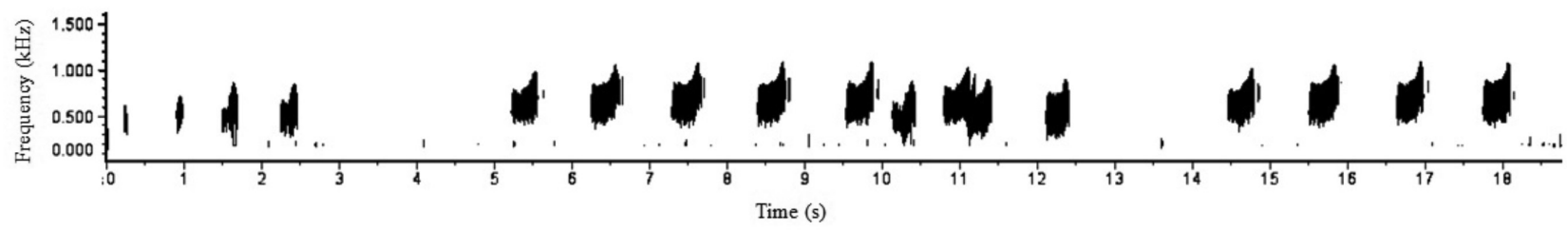

(a)

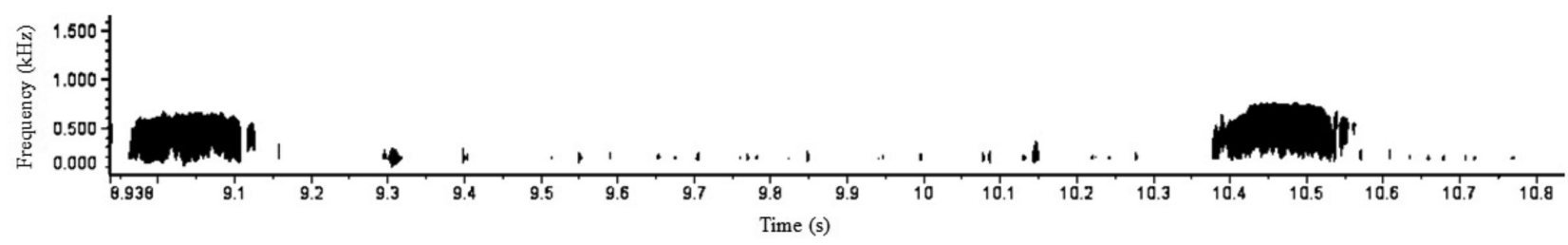

(b)

FIGURE 6. Spectrograms of duets recorded from two Brown Boobooks (a) and two Spotted Wood-Owls (b)

TABLE 1. Results of Wilcoxon signed-rank tests for vocal parameters measured for the duets of the three owl species

\begin{tabular}{|c|c|c|c|c|c|}
\hline & Parameter & $\begin{array}{l}\text { Lower pitch } \\
\text { Mean } \pm \text { SD }\end{array}$ & $\begin{array}{l}\text { Higher pitch } \\
\text { Mean } \pm \text { SD }\end{array}$ & $\mathrm{Z}$ & $\mathrm{P}$ \\
\hline \multirow{8}{*}{$\begin{array}{l}\text { Sunda Scops-Owl } \\
\text { (Pair 1) }\end{array}$} & $\mathrm{ND}(\mathrm{sec})$ & $0.23 \pm 0.01$ & $0.25 \pm 0.00$ & -2.859 & $0.004 *$ \\
\hline & INTD (sec) & $11.40 \pm 0.87$ & $18.34 \pm 2.58$ & -2.803 & $0.005^{*}$ \\
\hline & $\mathrm{SF}(\mathrm{Hz})$ & $431 \pm 4.07$ & $567 \pm 7.99$ & -2.805 & $0.005^{*}$ \\
\hline & $\mathrm{EF}(\mathrm{Hz})$ & $431 \pm 4.07$ & $554 \pm 11.62$ & -2.807 & $0.005 *$ \\
\hline & $\mathrm{LF}(\mathrm{Hz})$ & $431 \pm 4.10$ & $546 \pm 6.40$ & -2.803 & $0.005^{*}$ \\
\hline & $\mathrm{HF}(\mathrm{Hz})$ & $1023 \pm 6.02$ & $1319 \pm 11.79$ & -2.810 & $0.005^{*}$ \\
\hline & $\mathrm{MF}(\mathrm{Hz})$ & $689 \pm 0.00$ & $896 \pm 72.65$ & -2.972 & $0.003 *$ \\
\hline & $\operatorname{MFF}(\mathrm{Hz})$ & $689 \pm 0.00$ & $896 \pm 72.65$ & -2.972 & $0.003^{*}$ \\
\hline \multirow{8}{*}{$\begin{array}{l}\text { Sunda Scops-Owl } \\
\text { (Pair 2) }\end{array}$} & $\mathrm{ND}(\mathrm{sec})$ & $0.18 \pm 0.01$ & $0.18 \pm 0.01$ & -1.540 & 0.124 \\
\hline & INTD (sec) & $12.45 \pm 0.99$ & $10.77 \pm 0.79$ & -2.701 & $0.007 *$ \\
\hline & $\mathrm{SF}(\mathrm{Hz})$ & $501 \pm 6.40$ & $600 \pm 9.50$ & -2.805 & $0.005^{*}$ \\
\hline & $\mathrm{EF}(\mathrm{Hz})$ & $512 \pm 7.31$ & $600 \pm 9.50$ & -2.807 & $0.005^{*}$ \\
\hline & LF $(\mathrm{Hz})$ & $500 \pm 6.89$ & $600 \pm 9.45$ & -2.807 & $0.005 *$ \\
\hline & $\mathrm{HF}(\mathrm{Hz})$ & $1086 \pm 24.31$ & $1293 \pm 16.61$ & -2.803 & $0.005^{*}$ \\
\hline & MF (Hz) & $741 \pm 83.18$ & $1034 \pm 0.00$ & -2.919 & $0.004 *$ \\
\hline & $\operatorname{MFF}(\mathrm{Hz})$ & $827 \pm 72.61$ & $1034 \pm 0.00$ & -2.972 & $0.003 *$ \\
\hline \multirow[t]{8}{*}{ Brown Boobook } & TND (sec) & $0.33 \pm 0.01$ & $0.38 \pm 0.02$ & -2.823 & $0.005 *$ \\
\hline & INTD (sec) & $1.12 \pm 0.04$ & $1.11 \pm 0.05$ & -0.614 & 0.539 \\
\hline & $1^{\text {st }} \mathrm{SF}(\mathrm{Hz})$ & $220 \pm 4.22$ & $382 \pm 7.55$ & -2.831 & $0.005 *$ \\
\hline & $1^{\text {st }} \mathrm{LF}(\mathrm{Hz})$ & $220 \pm 4.22$ & $382 \pm 7.55$ & -2.831 & $0.005 *$ \\
\hline & $1^{\mathrm{st}} \mathrm{HF}(\mathrm{Hz})$ & $809 \pm 6.03$ & $830 \pm 36.53$ & -1.684 & 0.092 \\
\hline & $2^{\text {nd }} \mathrm{EF}(\mathrm{Hz})$ & $384 \pm 15.51$ & $512 \pm 4.83$ & -2.812 & $0.005^{*}$ \\
\hline & $2^{\text {nd }} L F(H z)$ & $352 \pm 9.90$ & $407 \pm 4.83$ & -2.831 & $0.005 *$ \\
\hline & $2^{\text {nd }} \mathrm{HF}(\mathrm{Hz})$ & $951 \pm 12.62$ & $1062 \pm 17.19$ & -2.805 & $0.005^{*}$ \\
\hline \multirow[t]{6}{*}{ Spotted Wood-Owl } & $\mathrm{ND}(\mathrm{sec})$ & $0.13 \pm 0.01$ & $0.15 \pm 0.01$ & -2.842 & $0.004 *$ \\
\hline & INTD (sec) & $7.89 \pm 1.58$ & $9.66 \pm 3.25$ & -1.989 & $0.047 *$ \\
\hline & $\mathrm{LF}(\mathrm{Hz})$ & $90 \pm 0.10$ & $152 \pm 6.33$ & -2.812 & $0.005 *$ \\
\hline & $\mathrm{HF}(\mathrm{Hz})$ & $616 \pm 7.22$ & $743 \pm 12.97$ & -2.810 & $0.005^{*}$ \\
\hline & $\mathrm{MF}(\mathrm{Hz})$ & $293 \pm 83.18$ & $483 \pm 72.52$ & -2.871 & $0.004 *$ \\
\hline & $\operatorname{MFF}(\mathrm{Hz})$ & $345 \pm 0.00$ & $517 \pm 0.00$ & -3.162 & $0.002 *$ \\
\hline
\end{tabular}

$(\mathrm{ND}=$ note duration, $\mathrm{INTD}=$ internote duration, $\mathrm{TND}=$ total note duration, $\mathrm{SF}=$ start frequency, $\mathrm{EF}=$ end frequency, $\mathrm{LF}=$ lowest frequency, $\mathrm{HF}=$ highest frequency, MF = maximum frequency and MFF = mean fundamental frequency, ${ }^{*}-$ at $5 \%$ significance level) 
Despite the survey was carried out during the breeding seasons, we only obtained four duets for the three owl species. We suspected that this was due to our survey period which was only restricted to $1900-0100 \mathrm{~h}$ and an extended survey throughout the night may be needed to understand the complete duetting activity pattern of these birds. It is worth to investigate if duetting in the three owl species represents cooperative effort of the sexes in territorial defence (Odom \& Mennill 2010) or otherwise (Fedy \& Stutchbury 2005).

\section{CONCLUSION}

All the three strigids uttered distinct territorial calls which were commonly heard at the study sites and pairs sang duets at different frequency. Our findings serve as a baseline facilitating further behavioural study in the future with respect to vocalisations of the birds of the Sunda region as well as conspecific interactions, which may have been relatively overlooked as compared to temperate region.

\section{ACKNOWLEDGEMENTS}

We wish to thank Muhammad Syafiq Yahya, Muhamad Syafiq Che Shaffine and Sasidhran Selvadurai for their assistance in the field. We would also like to thank the Forest and Plantation Section, Sultan Idris Shah Forestry Education Centre (SISFEC), Universiti Putra Malaysia for the permission to access Ayer Hitam Forest Reserve. Our research was funded by the Ministry of Higher Education, Malaysia through the Fundamental Research Grant Scheme Project No. 07-01-13-1184FR.

\section{REFERENCES}

Catchpole, C.K. \& Slater, P.J.B. 2008. Bird Song: Biological Themes and Variations. 2nd ed. Cambridge: Cambridge University Press.p. 348.

Fedy, B.C. \& Stutchbury, B.J.M. 2005. Territory defence in tropical birds: Are females as aggressive as males? Behavioral Ecology and Sociobiology 58(4): 414-422.

Hall, M.L. 2004. A review of hypotheses for the functions of avian duetting. Behavioral Ecology and Sociobiology 55(5): 415-430.

Jeyarajasingam,A. 2012. A Field Guide to the Birds of Peninsular Malaysia and Singapore. 2nd ed. Oxford: Oxford University Press. p. 449.

King, B. 2002. Species limits in the Brown Boobook Ninox scutulata complex. Bulletin of the British Ornithologists' Club 122(4): 250-257.

König, C. \& Weick, F. 2008. Owls of the World. 2nd ed. London: Christopher Helm Publishers. p. 528.

Langmore, N.E. 1998. Functions of duet and solo songs of female birds. Trends in Ecology and Evolution 13(4): 136-140.

Lok, A.F.S.L., Lee, T.K. \& Lim, K.C. 2009. The biology of Otus lempiji cnephaues Deignan, the Sunda scops owl in Singapore. Nature in Singapore 2: 31-38.

Marshall, J.T. 1978. Systematics of smaller Asian night birds based on voice. Ornithological Monographs 25: 1-58.
Marshall-Ball, L., Mann, N. \& Slater, P.J.B. 2006. Multiple functions to duet singing: Hidden conflicts and apparent cooperation. Animal Behaviour 71(4): 823-831.

Martínez, J.A. \& Zuberogoitia, I. 2002. Factors affecting the vocal behaviour of eagle owls Bubo bubo: Effects of sex and territorial status. Ardeola 49(1): 1-9.

Najmi-Hanis, Z., Puan, C.L., Zakaria, M. \& Azhar, B. 2016. Home range and activity patterns of Sunda scops-owl in Peninsular Malaysia. Raffles Bulletin of Zoology 64: 28-32.

Odom, K.J.\& Mennill, D.J. 2010. Vocal duets in a nonpasserine: An examination of territory defence and neighbour-stranger discrimination in a neighbourhood of barred owls. Behaviour 147: 619-639.

Pilla, P., Puan, C.L., Lim, V.C., Azhar, B. \& Zakaria, M. 2018. Sunda scops-owl density estimation via distance sampling and call playback. Sains Malaysiana 47(3): 441-446.

Puan, C.L., Yong, D.L., Azhar, B., Phua, M.H. \& Lim, K.C. 2015. Ecological correlations of nocturnal bird assemblages in Malaysian Borneo. Forktail 31: 82-86.

Rasmussen, P.C., Allen, D.N.S., Collar, N.J., DeMeulemeester, B., Hutchinson, R.O., Jakosalem, P.G.C., Kennedy, R.S., Lambert, F.R. \& Paguntalan, L.M. 2012. Vocal divergence and new species in the Philippine Hawk Owl Ninox philippensis complex. Forktail 28: 1-20.

Sadanandan, K.R., Tan, D.J.X., Schjølberg, K., Round, P.D. \& Rheindt, F.E. 2015. DNA reveals long-distance partial migratory behaviour in a cryptic owl lineage. Avian Research 6: 25 .

Sangster, G., King, B.F., Verbelen, P. \& Trainor, C.R. 2013. A new owl species of the genus Otus (Aves: Strigidae) from Lombok, Indonesia. PLoS ONE 8(2): e53712.

Slater, P.J.B. \& Mann, N.I. 2004. Why do the females of many bird species sing in the tropics? Journal of Avian Biology 35: 289-294.

Yahya, M.S., Puan, C.L., Azhar, B., Atikah, S.N. \& Ghazali, A. 2016. Nocturnal bird composition in relation to habitat heterogeneity in small scale oil palm agriculture in Malaysia. Agriculture, Ecosystems and Environment 233: 140-146.

Yee, S.A., Puan, C.L., Chang, P.K. \& Azhar, B. 2016. Vocal individuality of Sunda scops-owl (Otus lempiji) in Peninsular Malaysia. Journal of Raptor Research 50(4): 379-390.

Wachtmeister, C.A. 2001. Display in monogamous pairs: A review of empirical data and evolutionary explanations. Animal Behaviour 61: 861-868.

Siew Ann Yee, Chong Leong Puan* \& Phooi Kuan Chang Faculty of Forestry, Universiti Putra Malaysia 43400 UPM Serdang, Selangor Darul Ehsan Malaysia

Chong Leong Puan*

Institute of Tropical Forestry and Forest Products (INTROP)

Universiti Putra Malaysia

43400 UPM Serdang, Selangor Darul Ehsan

Malaysia

Chong Leong Puan*

Biodiversity Unit, Institute of Bioscience

Universiti Putra Malaysia

43400 UPM Serdang, Selangor Darul Ehsan

Malaysia 
*Corresponding author; email: chongleong@upm.edu.my

Received: 30 November 2017

Accepted: 9 March 2018 